\section{TERVEYSSOSIOLOGIAN LINJAT PITÄVÄT PINTANSA}

Ulla Buchert, VTT, tutkijatohtori, Helsingin yliopisto

Sakari Karvonen, Laura Kestilä \& Tomi Mäki-Opas (toim.): Terveyssosiologian linjoja, Gaudeamus, Tallinna. 2017, 299 s.

Terveyssosiologian linjoja alkaa toteamuksella "Terveyssosiologia tutkii terveyttä, sairautta, lääketiedettä ja terveydenhuoltoa" ja johdannon mukaan kirjan "tavoitteena on esitellä sosiaalitieteellisiä lähestymistapoja terveyden, sairauden ja terveydenhuollon peruskysymyksiin". Kirja jakautuu kahteen osaan, joista ensimmäisessä kuvataan sosiologisia lähestymistapoja terveyden tarkasteluun ja toisessa esitellään terveyssosiologisen tutkimuksen tuoreita näkökulmia ja analyyseja.

Kirjan artikkelit ovat hyvin kirjoitettuja ja huolellisesti toimitettuja. Vakuuttavassa kirjoittajajoukossa on mukana jopa 26 tohtoria. Artikkelit ovat teoreettisesti ansiokkaita ja useimmissa niistä käsitellään nimenomaan isoja linjoja. Artikkelit ovat niin täynnä asiaa ja näkökulmia, että niiden lukeminen vaatii paneutumista. Kirja lieneekin suunnattu ennen kaikkea tutkijoille, asiantuntijoille ja opiskelijoille. Yleisvaikutelma on ehkä kuitenkin aavistuksen verran paperinmakuinen. Ajatukset hiipivät totisen terveysvalistuksen suuntaan kerran jos toisenkin, vaikka artikkeleiden asiasisältö ei annakaan siihen aihetta.
Kirjassa käsitellään terveyssosiologian tärkeistä perusaiheista terveyden suhdetta eriarvoisuuteen, elämäntyyliin ja elämänkulkuun sekä terveyskäyttäytymisen sosiaalisia ja kulttuurisia ulottuvuuksia. Vähemmän tunnettuja aiheita edustavat luvut, joissa lähestytään terveyttä tieteen- ja teknologian tutkimuksen, ruuan ja syömisen muiden ulottuvuuksien, oppimisvaikeuksien ja ulkomaalaistaustaisen väestön näkökulmista. Sitä vastoin artikkeli, jossa esitellään etnografiaa tutkimusmenetelmänä ja laitosetnografian erityispiirteitä, jää aika kauas terveydestä, eikä oikein istu osaksi kokonaisuutta.

Kirjan parhaaksi anniksi nousee pyrkimys tarkastella eri aiheita samanaikaisesti yksilön ja yhteiskunnan, toiminnan ja rakenteen näkökulmista. Yhteiskunnan ja rakenteiden esiin nostaminen tuntuu tässä yhteydessä raikkaalta tuulahdukselta, eikä lainkaan menneiden aikojen pölyiseltä puuhalta, joksi se leimataan nykyisin helposti. Vaikutelma taitaa syntyä ennen kaikkea vastareaktiona sille, kuinka julkisissa terveyskeskusteluissa korostetaan yhä voimallisemmin yksilön valtaa ja vastuuta terveyteen vaikuttavista valinnoistaan sekä käsitellään terveyttä ja sairautta yksilön omana ansiona tai vikana. On helppo olla samaa mieltä kirjan loppuluvussa esitetyn väittämän kanssa, jonka mukaan "Terveyssosiologian vahvuus onkin, että se laajentaa näkökulmaa terveyttä, sairauksia ja elämäntapoja sekä niiden eriarvoisuutta määrittävien biologisten ja psykologisten tekijöiden lisäksi sosiaalisiin oloihin ja rakenteisiin sekä näiden vuorovaikutukseen." 
Kahden kirjan artikkelin ajankohtaisuus näyttää vain kasvaneen kirjan julkaisemisen jälkeen. Ensiksi, Päivi Topon ikääntymistä ja medikalisaatiota käsittelevää artikkelia lukee väkisinkin vanhusten hoivapalvelujen nykytilasta käytyjen keskustelujen valossa. Topo tuo esiin, että ikääntymistä ja erityisesti vanhuutta tarkastellaan korostetun terveysongelmakeskeisesti, kasvavana kyvyttömyyden ja avuttomuuden, palvelujen tarpeen ja heikkenevän huoltosuhteen ilmentymänä, jossa vanhuus heikentymisestä ja haavoittuvuudesta huolimatta toivottavana ja monimuotoisena elämänvaiheena jää toisarvoiseksi.

Toiseksi, Lauri Kokkisen, Pekka Varjen ja AriVäänäsen työtä ja terveyttä muuttuvissa hyvinvointivaltioissa käsittelevä artikkeli tarjoaa tärkeän näkökulman työperäisiin terveysongelmiin. Tutkijat kritisoivat työhyvinvoinnin kysymysten redusoimista henkilöön tai lähiympäristöön ja nostavat niiden rinnalle makrososiaalisen ja historiallisen kontekstin merkityksen. Artikkelissa tuodaan esiin tutkimuksiin perustuen, että työnantajat saattavat yrittää siirtää vastuuta työkuormituksen hallinnasta työnantajalta työntekijöille yksilön stressinhallintamenetelmiä painottavan lähestymistavan avulla, vaikka suurin osa työntekijöiden kokemista psykososiaalisista haitoista aiheutuu työn huonosta organisoinnista ja kiristyneestä taloudellisen hyödyn tavoittelusta.

Kirjan selkeästi suurin puute on se, ettei siinä ole mukana oikeastaan lainkaan terveydenhuoltoa koskevaa tutkimusta. Valinta herättää hämmästystä etenkin johdannossa esitettyjen tavoitteiden va- lossa. Kirjan toimittajien mukaan siitä jouduttiin jättämään väistämättä pois useita olennaisia teemoja, joihin lukeutuivat esimerkiksi potilaan ja lääkärin vuorovaikutus sekä terveydenhuolto. Kirjan ainoaksi kurotukseksi terveydenhuollon suuntaan jää Antero Olakiven terveyden ammattilaisia professiososiologian näkökulmasta käsittelevä artikkeli. Terveyden ja sairauden kaikki muut kytkökset esimerkiksi hoitoon hakeutumiseen, pääsemiseen ja siitä hyötymiseen, terveydenhuollon arkeen, ammattilaisten rooleihin, ammatillisiin käytäntöihin, terveydenhuollon töiden organisointiin ja johtamiseen, sekä terveydenhoidon järjestämisen tapoihin jäävät kokonaan kirjan ulkopuolelle.

Kaiken kaikkiaan Terveyssosiologian linjoja on korkeatasoinen ja ansiokas kokoomateos, jonka artikkelit käsittelevät niin laajoja ilmiöitä ja kysymyksïä, ettei niissä ehdi tapahtua muutamassa vuodessa kovin radikaaleja muutoksia. Toisaalta terveyssosiologisesti kiinnostavista ja ajankohtaisista tutkimusaiheista tuntuu olevan tällä hetkellä suorastaan runsaudenpulaa. Tutkimuksia tehdään muun muassa terveydenhuollon ja sairaudenhoidon digitalisaatiosta, uusien terveysteknologioiden käytöstä, asiantuntijatyön ajankäytön ongelmien ja kuormittavuuden terveysvaikutuksista, terveyden, sairauden ja hoidon transnationaaleista ulottuvuuksista sekä täydentävien ja vaihtoehtoisten hoitomuotojen käytöstä. 
YHTEISKUNTATIETEELLISEN TUTKIMUKSEN HÄIRITSEVYYTTÄ JÄLJITTÄMÄSSSÄ

Pekka Kuusela YTT, yliopistonlehtori, yhteiskuntatieteiden laitos, Itä-Suomen yliopisto

Valkonen, Jarno (toim.): Häiritsevä yhteiskuntatutkimus. Lapland University Press, Rovaniemi. 2018, 245 s.

Jarno Valkosen toimittama kirja häiritsevästä yhteiskuntatutkimuksesta on saanut lähtökohtansa sen pohdinnasta, miten yhteiskuntatiede voi vaikuttaa ja miten tämä vaikutus tapahtuu. Poliitikot käsittävät kysymyksen usein yksisuuntaisesti sellaisena, että yhteiskuntatieteet ovat jotenkin eriytyneet tai jääneet yhteiskunnan ulkopuolelle pohtimatta sitä, miten he loppujen lopuksi itse hyödyntävät poliittisessa päätöksenteossa tutkimusta. Suhde on toki kaksisuuntainen ja edellyttäisi myös poliittisten käytäntöjen ja hyvinvointivaltion institutionaalisen historian tarkastelua. Taloustieteilijöiden näkemykset menevät varmasti helpoiten läpi politiikassa, muttei taloustieteellinen tutkimuskaan ole mitenkään erityisesti vaikuttanut siihen, millaista talouspolitiikkaa Suomessa on tehty. Muiden yhteiskuntatieteiden aiheet saattavat olla sitten aihepiiriltään huomattavasti vaikeampi pala. Näkemyksiä ei koeta tärkeiksi tai niihin suhtaudutaan väheksyen. Tässä mielessä häiritsevyys tarkoittaa haluttomuutta antaa vastausta kysymyksiin tai ylipäänsä tarkastella koko asiaa.
Teos koostuu kahdeksasta artikkelista, jotka on jaettu teemoiltaan neljään laajempaan kokonaisuuteen. Nämä käsittelevät väliotsikoiden mukaan piiloutunutta väkivaltaa, ohikatsottuja läsnäolevia, tunnistamisen politiikkaa ja arkielämän katkoksia.Vaikka artikkelit ovat erilaisia ja poikkeavat toisistaan näkökulmaltaan, niitä kaikkia yhdistää muodossa tai toisessa yhteiskunnallisesti häiritsevien asioiden tarkastelu. Tieteenalan osalta monen kirjoittajan tausta on sosiologiassa, mutta näköala on monipuolisempi. Tarkastelun ja käytettyjen aineistojen luonne myös vaihtelee, mikä on tavallista toimitetuissa kirjoissa. Muutamissa artikkeleissa sisältö on hyvinkin konkreettinen, eikä laajempiin teoreettisiin tarkasteluihin mennä. Toisissa taas luodaan yleisempää kuvaa tarkasteltavasta aihepiiristä. Mukana on monipuolinen joukko toimijoita alkaen lapsista ja päättyen kirjoihin.

Kirjan aloittaa kaksi väkivaltaa käsittelevää artikkelia. Ensimmäisessä (Merja Laitinen, Anna Nikupeteri ja Johanna Hurtig) kuvataan lasten näkökulmasta eron jälkeistä vainoa. Kyse on toisin sanoen lastensuojeluun liittyvästä ilmiöstä, jossa perheen isä tai isäpuoli vainoaa perhettä eron jälkeen. Tarkastelu perustuu lasten haastatteluaineistoon. Sen pohjalta lapset eivät ole passiivisia sivustaseuraajia, vaan heillä on eritasoista tietoa vainosta. Tämä tieto luokitellaan monipuolisesti artikkelissa. Samalla valotetaan lasten tietävän toimijuuden ulottuvuuksia passiivisuudesta aktiivisuuteen. Toisessa artikkelissa Aini Linjakumpu erittelee hengellisessä yhteisössä ilmenevää väkivaltaa verkko- ja sanomalehtiaineiston pohjalta. 
Yksinkertaistaen näkökulmana on se, että hengelliset yhteisöt ovat poliittisia ja valtaa käyttäviä yhteisöjä. Hengellinen väkivalta kohdistuu yhteisön omiin jäseniin. Tyypillistä on, että yhteisöt pyrkivät yleensä torjumaan väkivallan olemassaolon ja suhtautuvat asian käsittelyyn kielteisesti. Tästä syntyy asian häiritsevä puoli, ja yllättävää on, miten myöhään ilmiö on tullut yhteiskunnassa ja tutkimuksessa esille, kuten Linjakumpu mainitsee artikkelinsa loppupuolella.

Toisen teeman yhteydessä sukelletaan huume- ja jätepolitiikkaan. Ensimmäisessä artikkelissa (Sanna Hautala, Pekka Hakkarainen, Kati Kataja, Sanna Kailanto ja Christoffer Tigerstedt) pohdintaan sitä, miksi huumeisiin liittyvä mielihyvä on torjuttu teema tutkimuksessa. Yhteiskuntatieteissä mielenkiinto on ollut huumeiden haittojen, riskien ja seurausten tarkastelussa. Kirjoittajat siis haastavat perinteistä tutkimusta. Tarkastelu perustuu Suomen Akatemian rahoittamassa hankkeessa kerättyyn aineistoon, jota tekijät ovat eritelleet sisällönanalyysin pohjalta. Sen mukaan huumeiden mielihyväkäyttö jakautuu vapaa-aikaan ja hauskanpitoon, rituaaleihin ja itsetuntemukseen sekä addiktiiviseen käyttöön. Toisessa artikkelissa Jarno Valkonen valottaa yleisellä tasolla ympäristösosiologian alaan liittyviä kysymyksï jätehuollosta, jätteen yhteiskunnallisesta merkityksestä ja jätepolitiikan muutoksista. Lähtökohtana on lyhyt uutinen, jossa kerrotaan jätteen määrän putoamisesta parissa kuukaudessa viidenneksellä, mikä on pakottanut jäteyhtiöt korottamaan maksujaan kymmenen prosenttia. Tästä lyhyestä tilannekatsauksesta avautuu kehys siihen, mikä on jätteen asema yhteiskunnassa ja miksi eri osapuolilla on erilaiset intressit.
Kirjan kolmas teema liittyy tasa-arvoon, sukupuoleen ja etnisiin vähemmistöihin. Sitä käsittelee kaksi erillistä artikkelia. Ensimmäisessä Kirsti Lempiäinen erittelee haastattelujen, dokumenttiaineiston ja osallistuvan havainnoinnin pohjalta Suomen Akatemian strategista tutkimushakua ja sen näkemystä tasa-arvosta. Tämän julkisen haun tasa-arvokäsitys on vahvasti yleistävä ja puhuu yleisellä tasolla asiasta ottamatta huomioon sukupuolta. Se johtaa ongelmalliseen näkemykseen, sillä tasa-arvon käsitettä voidaan pitää tekijän mukaan monimutkaisena, eikä sukupuolen merkitystä yleensä havaita tasa-arvon yhteydessä. Toisessa artikkelissa (Sanna Valkonen, Sami Kotiranta ja Saara Tervaniemi) tehdään yksityiskohtainen läpileikkaus Yhdysvalloissa ja Kanadassa esiintyneestä alkuperäiskansaan identifikaatiosta. Tarkastelussa ei käytetä omaa aineistoa, vaan käydään läpi aihepiiriä koskevaa tutkimusta ja selitetään sitä, miksi identiteetin vaihtaminen voi olla häiritsevä asia. Siten alkuperäiskansojen identiteetti ja asema ei ole mitenkään yksiselitteinen tai ristiriidaton asia. Tilannetta selittävät yhteiskunnalliset ja poliittiset tekijät, jotka ovat muuttaneet näiden ryhmien asemaa.

Kirjan neljäs teemakokonaisuus on nimetty "Arkinen katkos"-otsikolla. Se ei välttämättä avaudu heti lukijalle, ja näkökulmakin on harvinaisempi. Ensimmäisessä artikkelissa Sandra WalleniusKorkalo erittelee Pauliina Rauhalan romaaniin Taivaslaulu perustuvaa teatteriesitystä. Yhteiskunnallinen teema astuu esiin siitä, miten teatteriesitys antaa sisällön ja muodon lestadiolaisuudelle. Artikkelin polttopisteessä on se, miten näytelmä tuo esille lestadiolaista 
ruumiillisuutta ja millaisen ymmärryksen se tuottaa uskonnollisuudesta. Lähtökohtana on Judith Butlerin ajattelu. Analyysi pohjautuu näytelmään ja sen näyttelijöiden haastatteluihin. Toisessa artikkelissa Veera Kinnusen aiheena ovat puolestaan kirjat, kun ihminen muuttaa ja joutuu karsimaan omaisuuttaan. Artikkeli perustuu tekijän väitöskirjaan esinesuhteista muutossa. Erittelyssä kuvataan sitä, miten suhde esineisiin - tässä tapauksessa kirjoihin jäsentyy muuton eri vaiheissa ja mikä on yleisemmin kirjan kohtalo nykyyhteiskunnassa.

Kirja tuo kiinnostavan lisän siihen, mitä on viime aikoina kirjoitettu yhteiskuntatieteellisen tutkimuksen tilanteesta. Vaikka teoksen sisällöllistä asetelmaa ja näkökulmaa olisi voinut tarkentaa, häiritsevyyden teema liittää kiinnostavalla tavalla erillisiä tarkasteluja yhteen. Johdantoluku avaa hyvin kokonaisuutta. Monet aihepiireistä ovat sellaisia, jotka vaatisivat ehdottomasti enemmän tarkastelua ja joilla on yleisempää yhteiskunnallista merkitystä. Yhteiskuntatieteiden kriittinen lähestymistapa on usein sellainen, jota ei mediassa tai poliitikkojen puheessa ymmärretä. Tilalle halutaan helppoja ratkaisuja, joita tutkimus ei yleensä koskaan voi tuottaa, kuten kirjan toimittanut Valkonen toteaa alkupuolella. Häiritsevä yhteiskuntatutkimus -kirja tuo vaihtoehdoksi sen, että yhteiskunnallisesti vaikeiden ja häiritsevyyttä herättävien asioiden yhteydessä tutkimus on kuitenkin tarpeellinen ja välttämätönkin osa itse asian ratkaisua, jotta nähdään koko ongelman luonne kaikessa laajuudessaan.

\section{ÄITIYDEN TUNNERAKENNE TALOUSKURIPOLITIIKAN BRITANNIASSA}

Armi Mustosmäki, YTT, KTM, tutkijatohtori, sukupuolentutkimus, Yhteiskuntatieteiden tiedekunta, Tampereen yliopisto

Jensen, Tracey: Parenting the crisis. The Cultural politics of parent-blame. Policy press, University of Bristol. 2018, 205s.

Nykyään vanhempia usein vastuutetaan sellaisista lasten ja nuorten ongelmista ja elämäntapahtumista, joita ennen pidettiin kohtalosta, huonosta onnesta tai yhteiskunnallisista olosuhteista johtuvina, kuten vaikkapa ylipaino, huumeiden käyttö, rikollisuus, tai heikko koulumenestys. Tracey Jensenin, tuoreen kirjan Parenting the crisis. The Cultural politics of parent-blame lähtökohtana on henkilökohtainen kokemus äitinä ja ihmetys siihen, miksi vanhempia, erityisesti äitejä, ohjeistetaan, vastuutetaan, syyllistetään ja kontrolloidaan mitä erilaisimmissa tilanteissa. Vanhempien syyllistämisen koneisto jyllää raskaudenseurannassa, lasten kasvatuksen asiantuntijalausunnoissa, sosiaalisen median keskusteluforumeilla ja vanhempien omissa juoruringeissä, kulmien kohotteluna päiväkodin porteilla.

Tätä taustaa vasten Jensen asettaakin tavoitteekseen jäljittää perheiden ja vanhemmuuden, erityisesti äitiyden, ympärillä vallitsevaa 'nykyisyyden tunnerakennetta' (structures of feeling: Williams 1961). Tunnerakenteen voi ymmärtää eräänlaiseksi pysäytyskuvaksi liikkuvasta ja muuttuvasta todellisuudesta, joka pyrkii vangitsemaan yhtei- 
sön jakamia affektiivisia merkityksiä ja arvoja. Jensen kysyy, millaisessa kulttuurisessa ilmapiirissä äidit ja perheet elävät pitkittyneen talouskriisin Britanniassa. Kirjan keskeinen päämäärä onkin nostaa esiin, miten vanhempia syyllistävä puhe on yksilöllistänyt perheiden ongelmat ja niiden ratkaisut siten epäpolitisoiden ja siirtäen huomion pois Briteissä jo pitkään käynnissä olleesta hyvinvointivaltion kutistamisen projektista, jonka Jensen näkee koskettaneen (lähes) kaikkia perheitä.

Tracey Jensen on brittiläinen tutkija, jonka tutkimus liikkuu sosiaalipolitiikan, sosiologian, mediatutkimuksen ja sukupuolen tutkimuksen kentillä. Kirja Parenting the crisis kokoaa upeasti yhteen 10-vuotisen tutkijan uran keskeiset artikkelit ja teemat - äitiyden mediaesitykset, hyvinvointivaltion kurjistamispolitiikka, eriarvoisuus ja uusliberalismi - yhteen. Jensen on käyttänyt tutkimuksiensa aineistoina monipuolisesti erilaisia poliittisia puheita ja politiikkadokumentteja, mediaesityksiä ja tekstejä, kuten tosi-TV-ohjelmia (mm. Supernanny, Bringing up baby), blogeja ja brittiläistä internetin anonyymia keskustelupalstaa (Mumsnet). Hän ei näe näitä täysin erillisinä hallinnan muotoina tai vallan ilmentyminä vaan kulttuurin tuotteina, jotka osaltaan tuottavat näkemystä siitä, miten "vanhemmuus on hukassa" ja juuri perheiden ongelmat johtavat suurempiin yhteiskunnallisiin ongelmiin. Ja käänteisesti: perheet ovat ratkaisu yhteiskunnallisiin ongelmiin.

Vaikka julkisuudessa useimmiten puhutaan neutraalisti vanhemmuudesta, sisällöt, merkitykset ja vastuut ovat voimakkaasti sukupuolittuneita - useimmiten kyse on siis äitiydestä. Mediatekstit, kuten blogit, internetin keskustelupalstat ja tosi-TV, ovat keskeisiä identiteetin rakentamisen ja luokan tekemisen paikkoja. Samalla ne kutsuvat erityisesti äitejä kertomaan "valinnoistaan" refleksiivisesti ja tuottamaan kunniallista minuutta. Niinpä esimerkiksi keskustelupalstoista ja blogeista ei välttämättä tule tasavertaisia, demokraattisia kohtaamisen ja vertaistuen paikkoja, vaan foorumeita, joissa äidit moraalisesti oikeuttavat omia valintojaan. Vanhemmuus on siis sarja erilaisia valintoja siitä, mikä juuri minulle ja lapselleni on "oikein". Kuitenkin nuo "oikeat valinnat" ovat lopulta yhdenmukaisia: keskiluokkaisia, asiantuntijatietoon perustuvia, aikaa ja resursseja vaativia panostuksia lapseen. Samalla joidenkin äitien "valinnat" tulevat koodatuiksi epäilyttäviksi, vähemmän punnituiksi, huonommiksi. Jokainen äiti on potentiaalisesti huono äiti, mutta työttömiä, yksinhuoltajia ja sosiaalietuuksiin turvaavia äitejä syyllistetään kärkevämmin.

Ongelmien yksilöllistäminen, huolipuhe ja pitkittynyt taloudellisen niukkuuden aika Jensenin analyysin mukaan vastuuttaa yksilöitä ja nimenomaan äitejä: "hyvinvointivaltioon ei pidä luottaa, mutta kuka tahansa voi pärjätä”. Hyvän vanhemmuuden käsikirjoitukset ovat kyllästettyjä meritokraattisilla ja post-feministisillä ihanteilla siitä, miten "kuka tahansa voi olla hyvä äiti”. Tosi-TV, kuten Suomessakin maaliskuussa 2019 ensi-iltansa saanut Supernanny, sivuuttaa täysin perheiden erilaiset lähtökohdat, työttömyyden, köyhyyden, (toisten) elämän prekaariu- 
den. Samalla keskiluokkaisen äitiyden ihanteet, kuten lempeä, keskusteleva kuri, äidin herkeämätön läsnäolo, yhteisten perheruokailujen ja ulkoilujen ympärille rytmitetty arki ja kodin järjestys, koodataan ainoiksi oikeiksi tavoiksi kasvattaa.

Vaikka hyvän ja huonon äidin rajapintojen tarkastelu, äitien syyllistäminen tai uusliberaalin hallinnan teemat eivät ole uusia tai raikkaita sinänsä, Jensenin teos on erityisen ajankohtainen ja laajempiakin yleisöjä kiinnostava. Hän ei rajaudu käsittelemään vanhempien syyllistämistä vain ilmiönä, joka kuvaa ajallamme tyypillistä intensiivisen, sensitiivisen ja riskejä hallitsemaan pyrkivää vanhemmuuden kulttuuria (esim. Lee ym. 2014). Sen sijaan Jensen onnistuu erinomaisesti laajentamaan analyysejään hyödyntämällä sosiaalipolitiikan ja feministisen luokkasensitiivisen tutkimuksen näkökulmia yhdistäessään vanhempien syyllistämisen ilmiöt laajempaan yhteiskunnalliseen ilmapiiriin ja erityisesti hyvinvointivaltion suunnanmuutokseen. Nämä sukupuolen, kulttuurintutkimuksen ja luokka-analyysin näkökulmat erottavat hänet myös monesta muusta yhteiskuntapolitiikasta ja vanhemmuuden kulttuurisesta tutkimuksesta julkaisevasta (britti)tutkijasta (ks. esim. Gillies ym. 2018; Lee ym. 2014; Macvarish 2016).

Jensen itse sijoittaa tutkimuksensa kulttuurintutkimuksen perinteeseen ja nimeää mm. Stuart Hallin tärkeäksi vaikuttajakseen. Jensenin kirjan nimi "Parenting the crisis" on jo itsessään tribuutti Stuart Hallin ja kumppaneiden tutkimukselle Policing the crisis: mugging, the state and law and order. Tutki- mus sijoittuu 1970-luvun Britanniaan kuvaten, miten julkisessa keskustelussa rakennettiin uhkakuva "ryöstelijästä", jolla perusteltiin politiikan suunnanmuutosta kohti autoritaarisempaa poliisilaitosta, hallintaa ja politiikkaa. Jensenin oma tutkimus noudattelee Hallin ideaa siitä, miten politiikan suunnanmuutos vaatii taakseen yleisen ilmapiirin muutoksen; "arkijärkisen" ymmärryksen siitä, mikä on ratkaisu kunkin ajan erityisiin ongelmiin.

Jensen tarttuu hallitusten ohjelmiin ja poliitikkojen kannanottoihin, joiden perusteella ilmeiseksi ongelmaksi 2008 talouskriisin jälkeisessä pysyvän budjettivajeen ja hitaan kasvun vaiheessa muodostuu "liian suuri ja kallis hyvinvointivaltio". Erityisen ongelman muodostavat sosiaaliturvaa tarvitsevat perheet. Jensen ruotii $\mathrm{mm}$. New Labourin (1997-2010) vanhemmuuden tukemisen ohjelmaa, jonka pääideat perustuivat havahtumiseen huono-osaisuuden periytyvyydestä: erilaiset (yhteiskunnalle kalliit) sosiaaliset ongelmat kuten huono terveys, alhainen koulutustaso, toimeentulotuen käyttö ja monet muut eriarvoisuuden muodot johtuvat henkilön taustasta. Vanhemmuuden tukemisen kirkkain tavoite olikin selvittää, miten irrottaa lapset huono-osaisuuden ylisukupolvisesta ketjusta.

Pysyvän talouskurin ilmastossa keskeiseksi työkaluksi nouseekin kasvatus ja miten ohjata vanhempia siihen, miten he voivat, taloudellisista resursseistaan riippumatta, kasvattaa lapsistaan pärjääviä, itsestään huolehtivia resilienttejä kansalaisia. Jensen käy läpi myös Cameronin pääministerikauden (2010-2016) poliittista retoriikkaa, jossa vanhempi- 
en lämpö ja rakkaus nostaa lapsen taloudellisen kurjuuden ja osattomuuden yläpuolelle. Jensen viittaakin Nancy Fraseriin (2013) tulkitessaan, ettei politiikan tavoite enää olekaan köyhyyden vähentäminen vaan sosiaaliturvariippuvuuden vähentäminen.

Samaan aikaan mediaesitykset ja tosiTV:n "köyhyysporno" (poverty porn) patologisoi vähävaraisia perheitä vastuuttomiksi, kyvyttömiksi tekemään oikeita valintoja ja kieltämään itseltään ja "pärjäämään ilman". Kulttuurinen myytti, joka kutsutaan apuun, on fantasiaperhe menneisyydestä, taloudellisesti vastuullinen ja säästäväinen, pärjäävä, itsehillintään kykenevä, kekseliäs, resilientti, kiitollinen ja moraalisesti suoraselkäinen. Tätä säästäväisyyden ja pärjäävän kansalaisen ihannetta Jensenin analyysissä tukevat myös erilaiset kotoilublogit ja tosi-TV-formaatit, joissa opetetaan kadonneita kotitalous- ja kädentaitoja niukkuutta ja menneitä aikoja romantisoiden. Talouskuri välittyykin ihanteeksi sekä kotitalouden pyörittämiseen että kansalliseen politiikkaan.

Tässä onkin mielestäni kirjan paras anti: teos valaisee, miten erilaisissa mediateksteissä, poliittisissa puheissa ja arkisissa käytännöissä tuotetaan ja kierrätetään käsityksiä 'hukassa olevista vanhemmista', 'huonoista äideistä' ja 'ongelmaperheistä', sosiaaliturvariippuvuudesta, 'sosiaalipummeista', ja kannustinloukuista ja miten nämä yhdistyvät hyvinvointivaltion kurjistamiseen, vastikkeellisen sosiaaliturvan ja talouskuripolitiikan kannatukseen. Vaikka kirjan analyysit sijoittuvat Britanniaan, tuntuvat ne hyvin ajankohtaisilta myös suomalaista vanhemmuuskulttuuria ja hyvinvointivaltion suunnanmuutoksia seuraaville ja tutkiville.

\section{KiRJALlisUUS}

Fraser, Nancy (2013) Fortunes of feminism. From state-managed capitalism to neoliberal crisis. London:Verso.

Gillies, Val \& Edwards, Rosalind \& Horley, Nicola (2018) Challenging the politics of early intervention: Who's saving children and why? Bristol: Policy press. https://doi.org/10.1332/policypress/9781447324096.001.0001

Hall, Stuart \& Critcher, Chas \& Jefferson, Tony \& Clarke, John \& Roberts, Brian (1978) Policing the crisis: mugging, the state and law and order. London: Palgrave Macmillan.

Lee, Ellie \& \& Bristow, Jennie \& Faircloth, Charlotte \& Macvarish, Jan (2014) Parenting culture studies. London: Palgrave Macmillan. https://doi. org/10.1057/9781137304612

Macvarish, Jan (2016) Neuroparenting. The Expert invasion of family life. London: Palgrave Macmillan. https://doi. org/10.1057/978-1-137-54733-0

Williams, Raymond (1961) The long revolution. Ontario: Broadview Press. 
MONENKESKISTÄ VASTAVUOROISUUTTA HAKEMASSA

Pauli Niemelä, professori emeritus, ItäSuomen yliopisto

Hallamaa, Jaana: Yhdessä toimimisen etiikka. Gaudeamus, Helsinki. 2017, $320 \mathrm{~s}$.

Helsingin yliopiston sosiaalietiikan professori Jaana Hallamaa on laatinut yhteistoiminnan etiikkaa koskevan kirjajärkäleen. Teos vyöryttää monisataisilla sivuilla esiin varsinaisen käsitteistöjoukon. Tekstiä pyritään tiivistämään lukuisilla, joskus varsin vaikeastikin avautuvilla, abstraktiotasoltaan vaativilla taulukoilla (15 kpl) ja yhdellä kuviolla. Mihin Hallamaa tähtää teoksellaan?

Kirjan ensimmäisenä tavoitteena, kuten Hallamaa itse muotoilee, on hyödyntää yhdessä toimimiseen liittyviä käsitteitä ja filosofisia muotoiluja erityyppisen yhteistoiminnan analysoimiseen. Hallamaa on tarkastellut toimimisen merkityksiä tekemällä runsaasti käsitteellisiä erotteluja sekä hyödyntämällä eri ihmistieteiden edustajien ajattelua. Tällä tavalla tekijä on selvittänyt monin tavoin sekä spontaanin että vaikuttamalla aikaan saadun yhteistoiminnan ehtoja ja luonnetta.

Tämän ensimmäisen tavoitteen käsittelyyn tekijä on varannut peräti 255 sivua (14 lukua).Täten se muodostaa teoksen keskeisimmän annin. Toiseksi tavoitteekseen Hallamaa on asettanut luonnostella, miten yhdessä toimisen moraalista laatua voitaisiin arvioida ja parantaa.
Tähän aiheeseen tekijä on käyttänyt vain 29 sivua (luku 15). Jo tällä tavalla mitattuna, tämän toisen tavoitteen käsittely on jäänyt lähinnä luonnosteluksi. Kirjoittaja esittää tässä luvussa teoksensa normipäätymät. Tarkastelen niitä lopuksi.

Teos on luonteeltaan oppikirjamainen. Se analysoi hyvin monipuolisesti yhdessä toimisen eettisiä kysymyksiä laajentaen näin tarkastelunsa perinteisistä moraalifilosofisista kysymyksistä erityisesti ihmisten välistä yhteistoimintaa koskeviksi, sosiaalisiksi kysymyksiksi. Hallamaa vyöryttää esiin niitä käsitteellisiä välineitä, joiden avulla yhdessä toimimista ja sen periaatteita voidaan ymmärtää.

Hallamaa analysoi kirjansa alussa varsin seikkaperäisesti toiminnan käsitettä. Toimijaksi Hallamaa määrittelee henkilön, joka 1) kykenee asettamaan päämäärï (intentionaalisuusehto), 2) joka ymmärtää syy-seuraussuhteita ja osaa arvioida niitä (järkevyysehto) sekä 3) joka pystyy toiminnallaan tavoittelemaan asettamiaan päämääriä (kyvykkyysehto). Taulukossa 1 tekijä esittää kiinnostavan analyysin erilaisista toimintatyypeistä. Seuraavaksi tekijä tarkastelee tärkeää praktista syllogismia, sen "modus ponens" ja "modus tollens" muotoja eli toiminnassa sen riittävää ja välttämätöntä ehtoa. Niin ikään tekijä käy läpi aristoteeliset toiminnan eri muodot (poiesis, praksis ja theoria).

Hallamaa erittelee seuraavaksi ansiokkaasti hyvää, moraalisesti hyvää toimintaa, lähimmäisen hyvää ja luottamusta. Sen jälkeen hän keskittyy vallan ohella erityisesti vaikuttamisen kysymyksiin 
arvostellen mm. sellaista toimintaa, jossa toiminnan toinen osapuoli välineellistetään. Kirjan yksi läpitunkeva teema on hyvän tekemisen ja pahan välttämisen analysointi.

Hallamaa osoittaa, miten hyvän tekemistä ja pahan välttämistä ehkä vielä vaikeampaa on tunnustaa toinen osapuoli tasaveroiseksi toimijaksi. Hallamaa päätyykin yhdessä toimimisen etiikan kantavaan ihanteeseen, so. monenkeskiseen vastavuoroisuuteen. Tässä mielessä teos on hyvä lisä sosiaalityössä jo julkaistuun vastavuoroiseen sosiaalityöhön.

Monenkeskisen vastavuoroisuuden periaate on vaativa, koska se edellyttää toimijoiden tunnistavan toisensa ja riippuvuutensa toisistaan sekä vielä sitoutuvan toiminnassaan vastavuoroisuuteen. Kyseessä on moneuden tunnistaminen ja tunnustaminen sekä jatkuva dialogi hyvästä, sen näkemisestä eri tavoin.

Paikka paikoin Hallamaan käyttämä termistö on hieman oudohko, ja joissakin kohdin on tarpeetonta toistoa. Tällainen avautuu muun muassa eitoimisen kuvauksesta. Ehkä kuitenkin hankalimpia ovat eräät mammuttimaiset taulukot, erityisesti taulukot 8, 12, 13 ja 15. Näissä on asiaa ja tekstiä aivan liikaa, jotta taulukot selventäisivät ja tiivistäisivät sanottavaa. Lisäksi arvoja koskevan taulukon sisällöstä en ole täysin yhtä mieltä tekijän kanssa, kun hän luokittelee itseisarvoja ja niiden, osin aika kummallisiakin välinearvoja taulukossa 5 .

Hallamaa päätyy esittämään lopuksi kirjansa viimeisessä luvussa neljä lähimmäisen toimijuutta tukevaa normia.
Kukaan ei voi vaatia toiselta sellaista, mihin ei itse ole valmis.

Tätä normia Hallamaa avaa esimerkillä "maskulismista", joka tarkoittaa, että miehet pyrkivät määrittämään naissukupuolta. Puuttumatta tähän ajatukseen, kyselen yhteiskuntatieteilijänä sitä, että yhteiskuntien eri johtotehtävissä olevilta toki voidaan odottaa ja vaatia sen tehtävän mukaista toimintaa, mihin "jokamiehen" ei tarvitse olla valmis. Ehkäpä tässä paljastuu juuri teoksen mikromaailma.

Kukaan ei voi kieltää toisilta sellaista, mihin hän katsoo itse olevansa oikeutettu.

Tämän toisen normin esimerkkinä Hallamaa käyttää, aivan oikeutetusti, rasismia. Näin ollen toiselta toimijalta ei voida kieltää jotakin vedoten esimerkiksi rodulliseen erotteluun. Tätä normia on historian kuluessa loukattu varsin paljon.

Jokaisen on suotava muille se, mihin hän katsoo itse olevansa oikeutettu.

Tässä normissa Hallamaa käyttää esimerkkinä etuoikeutettua valta-asemaa, jota siis valta-aseman haltija ei saa väärin käyttää rajoittamalla muiden oikeuksia. Tämä normi nostaa esiin paljon kysymyksiä reaalisesta todellisuudesta, esimerkiksi taloudellisista eriarvoisuuksista.

Kukaan ei voi sitoa oikeuksiensa toteutumista tai identiteettinsä tunnustamista vaatimukseen saada kieltää toisilta jotain heidän ominaisuuksiensa tai identiteettinsä perusteella. 
Viimeistään tämä normi avaa teoksen punaisen langan. Hallamaan omin sanoin: "Vaatimus saada toteuttaa elämäntapaa, joka rajaa muiden toimintamahdollisuuksia heidän identiteettinsä perusteella, ei ole vastavuoroisuuden vaatimuksen mukaan oikeutettua."

Näillä normeilla Hallamaa on halunnut luonnostella sitä, millaisia edellytyksïä yhdessä toimimisen olisi täytettävä ihmisten välillä, jotta toiminta toteutuisi monenkeskisenä vastavuoroisuutena. Voi toivoa, että Hallamaa paneutuu jatkossa asettamaansa toiseen tavoitteeseen perinpohjaisemmin.

Summa summarum. Hallamaan teos koskee eritoten ihmistasoista ja ihmisten välistä toimintaa. Yhteiskunnalliset ja institutionaaliset tekijät ovat teoksessa vähemmällä tarkastelulla. Sosiaalietiikan professorina Hallamaa on keskittynyt mikrososiaalisiin, eettisiin kysymyksiin. Teoksen lähdeluettelo on vaikuttava. Ja erityisen mukavaa on lukea teosta, jossa on asianmukainen asiahakemisto lopussa. Kirja soveltuu oppikirjaksi niin etiikkaa ylipäänsä kuin myös tämän tasoista käytännön sosiaalista problematiikkaa käsittelevälle sosiaalityölle.

Voinee väittää, että koko teoksen läpitunkevana punaisena lankana pilkistää ihmistasoinen vastavuoroisuuden ikiaikainen normi, kultainen sääntö. Tämän positiivinen muotoilu kuuluu: "Kaikki, minkä tahdotte ihmisten tekevän teille, tehkää te heille". Säännöstä on myös johdettu negatiivinen versio, ortodoksisessa maailmassa niin kutsuttu "hopeinen sääntö”. Tämä säännön muotoilu kuuluu: "Älkää tehkö toisille mitään, mitä ette tahtoisi itsellenne tehtävän". Niinpä niin, mitenpä vastavuoroisuuden voisi kiteytetymmin ilmaista.

\section{JÄRKÄLE SOSIAALIPEDAGO- GISTA TIETÄMYSTÄ YKSISSÄ KANSISSA}

Tiina Sotkasiira, yliopistotutkija, $y^{h}$ teiskuntatieteiden laitos, Itä-Suomen yliopisto

Nivala, Elina \& Ryynänen, Sanna: Sosiaalipedagogiikka. Kohti inhimillisempää yhteiskuntaa. Gaudeamus, Helsinki. 2019, 422 s.

Elina Nivalan ja Sanna Ryynäsen kirjoittama teos Sosiaalipedagogiikka. Kohti inhimillisempää yhteiskuntaa on sekä johdatus sosiaalipedagogiseen ajatteluun ja toimintaan että laaja tietoteos, joka ammentaa tekijöidensä monipuolisesta kokemuksesta sosiaalipedagogiikan tutkijoina, opettajina ja kehittäjinä. Kulkien suomalaisen sosiaalipedagogiikan pioneerien Juha Hämäläisen ja Leena Kurjen jalanjäljissä, Nivala ja Ryynänen määrittelevät kirjassaan sosiaalipedagogiikan erityislaatua sekä tarjoavat sosiaalipedagogista lähestymistapaa työkaluksi kaikkeen kasvatukselliseen toimintaan, jossa ollaan kiinnostuneita yksilöistä, yhteisöistä ja yhteiskunnasta.

Sosiaalipedagogiikka määritetään kirjassa kolmen eri ulottuvuuden kautta. Siitä kirjoitetaan tieteenalana, käytännön työnä sekä koulutusalana, joissa yhdistyvät yhteiskuntatieteelliset ja kasvatustieteelliset näkökulmat. Näin sosiaalipedagogiikka määrittyy toiminnaksi, jolle on ominaista tarkastel- 
la yhteiskuntaa kasvatuksen ja toisaalta kasvatusta ihmisen ja yhteiskunnan suhteen näkökulmasta. Alan keskusteluiden moninaisuus tuo sävynsä myös kirjan sisältöihin. Nivala ja Ryynänen tutustuttavat lukijat sosiaalipedagogiikan teoreetikoihin ja vakiintuneisiin käsitteisiin, mutta kirjaan on omaksuttu näkökulmia ja käsitteitä myös muilta tieteenaloilta, kuten filosofian ja sosiologian nykykeskusteluista.

Kirja koostuu johdannosta ja kymmenestä sisältöluvusta, jotka jakautuvat kolmeen osaan. Kirjan ensimmäinen osa käsittelee sosiaalipedagogiikan historiaa sekä viime vuosikymmenten sosiaalipedagogista teoreettista keskustelua. Tekijät nostavat esille ajattelijoita, kuten Paul Natorp (1854-1927) ja Herman Nohl (1879-1960) sekä Ramón Ruiz Amadoa (1861-1934) ja Lorenzo Luzuriaga (1889-1959), joihin tutustumalla rakentuu kuva tieteenalan kehityksen alkuvaiheista. Tätä kehystystä laajennetaan kirjassa kuvaamalla, miten sosiaalipedagoginen ajattelu on vuosikymmenten aikana kehittynyt ympäri maailman erilaisten kansallisten tarpeiden ja traditioiden pohjalta.

Toisessa osassa käydään läpi sosiaalipedagogisen ajattelun ja toiminnan eri suuntauksia. Tilaa saavat niin sosiaalipedagogisen ihmiskäsityksen luonnehdinta kuin yhteisön ja yhteiselämän tarkastelu ihmisten välisten suhteiden, kasvun ja kasvatuksen ympäristöinä. Nivala ja Ryynänen käyvät myös keskustelua siitä, kuinka kasvu ja kasvatus yhteiskunnan jäsenyyteen tapahtuvat sekä pohtivat yhteiskunnallista ulkopuolisuutta ja keinoja puuttua siihen. Kolmannessa osassa perehdytään sosiaalipedagogiikan käytäntöihin ja hahmotellaan tietä eteenpäin kysymällä, miten sosiaalipedagogiikka vastaa esimerkiksi ekologiseen tai talouden eriarvoistumisen haasteeseen. Lopuksi kirjoittajat esittelevät sosiaalipedagogisen käytännön työn arviointia, jota he pitävät olennaisena osana sosiaalipedagogista työotetta sekä vievät lukijat sosiaalipedagogisen tutkimuksen maailmaan. Kirja on rakenteeltaan selkeä ja sen kieli on sujuvaa. Siihen sisältyvät kaaviot ja taulukot tiivistävät tekstistä olennaisen. Sen voi helposti kuvitella oppikirjaksi eri oppiaineisiin.

Kirjoittajat määrittelevät kolme sosiaalipedagogiikan tietoteoreettista otetta ja vievät ne käytäntöön nimeämällä kolme sosiaalipedagogista toimijaa tai tutkijatyyppiä. Nivalan ja Ryynäsen mukaan sosiaalipedagogit voidaan jakaa teknisiin toteuttajiin, rinnalla kulkijoihin sekä maailman muuttajiin, vaikka käytännön työssä nämä erilaiset toiminnan orientaatiot sekoittuvatkin. Uskon, että jokainen näistä toimijatyypeistä löytää itselleen jotain tästä kirjasta. Rinnalla kulkija saa työhönsä tukea pohdinnoista, jotka koskevat dialogista kohtaamista ja sosiaalipedagogiikan tapoja tukea yksilön potentiaalia ja vahvistaa toimijuutta. Maailman muuttaja puolestaan löytää kirjasta uusia ideoita ja saa inspiraatiota toimintaansa Paulo Freiren (1921-1997) ja muiden kriittisten ajattelijoiden työstä. Tekninen toteuttaja, jonka työote kirjoittajien mukaan kaipaa eniten sosiaalipedagogista "ravistelua", saattaa kuitenkin jättää kirjan hyllyyn, koska säikähtää sen paksuutta. Kirjan laajuus ja se, että tietyt havainnot toistetaan useita kertoja, voivat olla pedagogisia keinoja, jot- 
ka auttavat opiskelijaa ymmärtämään ja muistamaan kirjan keskeiset sisällöt. Tekninen toteuttaja, jonka itsestänikin aika ajoin työpaineiden puristuksissa löydän, kuitenkin toivoo saavansa tarvitsemansa tiedot tiiviissä ja helposti omaksuttavassa muodossa.

Lukijan työn helpottamiseksi kirja sisältää lukuisia tutustu teoreetikkoon -tietolaatikoita sekä laatikoihin sisällytettyjä esimerkkejä sosiaalipedagogisella otteella toteutetuista hankkeista ja työmuodoista ympäri maailman. Myös johdanto- ja johtopäätelmälukuihin on tiivistetty olennainen sisältö. Jään silti pohtimaan, missä muodossa sosiaalipedagogista osaamista tulisi tarjota niille, joilla ei ole aikaa tai tarmoa tarttua yli 400-sivuiseen kirjaan. Tästä joukosta todennäköisesti löytyvät ne, jotka työssään eniten hyötyisivät kirjan näkökulmista.

Yliopistolla työskentelevänä tutkijana luin kirjaa paitsi tutkimuksen, myös opetuksen ja ohjauksen kehittämisen näkökulmasta. Yhteiskuntatieteellisten oppiaineiden opetuksen tavoitteet kiteytetään usein kehotukseen ymmärtää ja muuttaa maailmaa. Esimerkiksi oman työnantajani, Itä-Suomen yliopiston yhteiskuntatieteiden laitoksen toimintaidea on kiteytetty lauseeseen "Ymmärrä yhteiskuntaa - muuta maailmaa!". Kun tätä slogania valittiin, pohdimme työyhteisössä, miten tärkeää on tieteellisten ja kriittisten ajattelutaitojen lisäksi antaa opiskelijoille välineitä opintojen jälkeiseen aikaan. Yliopistojen lisääntyneestä työelämäorientaatiosta huolimatta arvelen, että harvassa oppiaineessa ajatusta siitä, miten maailman muuttaminen voisi käytännössä tapahtua, on viety niin pitkälle kuin tässä sosiaalipedagogiikan perusteoksessa.

Kirjan monet esimerkit sijoittuvat kansalaistoiminnan tai sosiaalisen työn maailmaan eivätkä ole sellaisenaan sovellettavissa esimerkiksi (puolue)poliittisen vaikuttamisen alalle. Tästä huolimatta näen, että kirja antaa perusteet ja perustelut pohtia nykyistä tarkemmin käytännön valmiuksia, joita eri alojen yliopistokoulutuksen odotetaan opiskelijoille tuottavan. Mitkä ovat ne keinot, joilla vaikkapa yhteiskuntapolitiikan, sosiologian tai sosiaalityön opiskelijat valmistuttuaan maailmaa muuttavat? Oppivatko opiskelijat näitä taitoja osana opintoja vai rajataanko maailman muuttaminen ja vaikuttaminen yliopisto-opintojen ulkopuolelle? Kuuluvatko nämä kuitenkin opiskelijoiden vapaa-aikaan eli nonformaalin ja informaalin kasvun ja oppimisen alueille? Toisaalta niillä aloilla, joilla yhteys käytäntöihin on vahva, voidaan kirjan innoittamana pohtia, miten taataan kaikille opiskelijoille myös ne teoreettiset valmiudet, joita oman toiminnan kriittinen tarkastelu ja työn kehittäminen vaativat.

Mikä sitten on sosiaalipedagogiikan ydintä? Kirjoittajien mukaan sosiaalipedagogiikka toimii kolmella yhtä arvokkaalla, mutta toisiinsa kietoutuneella tasolla, eli kyse on yksilön, yhteisön ja yhteiskunnan tarkastelusta kasvun ja kasvatuksen näkökulmasta. Kirja tarjoaa välineitä näiden tasojen ja niillä tapahtuvan toiminnan teoretisoimiseen sekä yksilöiden kohtaamiseen ja yhteisöllisen kasvun tukemiseen. Meistä jokainen tarvitsee elämänsä aikana tukea, mutta toisaalta sosiaalipedagogiikalla 
on myös erityinen tehtävä yhteiskunnan kipukohtien ja epätasa-arvoisuuksien paljastajana ja niihin puuttujana. Nivalan ja Ryynäsen mukaan hyvä yhteiselämä rakentuu tasa-arvon, oikeudenmukaisuuden ja luovuttamattoman ihmisarvon periaatteille. Arvioimani kirja on tarkoitettu lukijan taustasta riippumatta kaikille, joita nämä teemat kiinnostavat.

\section{NARRATIIVINEN SOSIAALITYÖ}

Merja Tarvainen, tutkijatohtori, YTT, FM, Yhteiskuntatieteiden laitos, Itä-Suomen yliopisto.

Baldwin, Clive: Narrative social work. Theory and application. Policy Press, Bristol. 2013, 161 s.

Clive Baldwin on sosiaalityön professori ja monitieteisen narratiivisen tutkimuskeskuksen johtaja Kanadassa (St Thomas University). Baldwinin teos narratiivisesta sosiaalityöstä alkaa huomiolla, kuinka aiempi tutkimus sosiaalityön narratiivisuudesta on yllättävän vähäistä. Yllättävää tämä on siksi, että sosiaalityötä jos jotain voidaan pitää "ilmeisen narratiivisena" professiona. Baldwin taustoittaa huomiota ja kertoo, että joitain poikkeuksia lukuun ottamatta aiempi tutkimus on tarkastellut narratiivisuutta sosiaalityössä esimerkiksi eräänä työmenetelmänä tai tutkimuksen analyysimenetelmänä (ks. kuitenkin esim. Hall 1997). Baldwinin pääväite kuitenkin on, että sosiaalityö on läpikotaisin narratiivista.
Narratiivisuus ei ole yksittäinen työmenetelmä, vaan narratiivisuus läpäisee sosiaalityön arvoja, etiikkaa, toimijuuksia ja rakenteellista vaikuttavuutta. Sosiaalityötä tehdään narratiivisessa toimintaympäristössä eli kulttuurisen tarinavarannon tarjoamin resurssein, joita myös sosiaalityön on mahdollista muokata ja tarkastella kriittisesti. Esimerkiksi päätöksenteko- ja arviointiprosesseissa ovat käytössä kulttuurisen tarinavarannon resurssit kyseessä olevasta työkentän kohdeilmiöstä; samoin asiakkaan kuulluksi tulemisen ehdot ja edellytykset kiinnittyvät tarjolla oleviin tarinamalleihin. Kulttuuriset mallitarinat suuntaavat tulkintaa esimerkiksi asiakkaan elämäntilanteesta ja sosiaalityöstä yhteiskunnallisena toimintana. Kulttuurisista mallitarinoista voidaan käyttää myös esimerkiksi valtanarratiivin tai niin kutsun suuren tarinan käsitteitä. Kulttuuriset mallitarinat rakentavat jaettua ymmärrystä kohdeilmiöstä ja suuntaavat yksittäisen tarinan rakentumista, kun kertoja esimerkiksi kiinnittyy valtavirtaan tai vaihtoehtoisesti irrottautuu tai jää irralleen siitä.

Baldwinin kirjassa on kolme osiota, joista ensimmäinen johdattaa narratiivisuuteen ja peruskäsitteistöön ja toisessa keskitytään narratiivisuuteen ja sosiaalityöhön narratiivisen toimijuuden, ihmisoikeuksien ja sosiaalisen oikeudenmukaisuuden sekä etiikan ja sosiaalipolitiikan osalta. Kolmas osio koostuu narratiivisen sosiaalityön käytännöistä ja käytöstä eräillä sosiaalityön kentillä, joista mukana ovat lastensuojelu, mielenterveyden sosiaalityö ja sosiaalityön suhde vammaisuuteen. Baldwin on teoksen päätekijä, mutta eräät teoksen osioista hän on yhteiskirjoitta- 
nut muiden kanssa. Aloitusosion johdanto narratiiviseen teoriaan on laadittu yhdessä Brandi Estey-Burttin kanssa, joka on myös kirjoittanut itsenäisesti luvun mielenterveyden sosiaalityön narratiivisuudesta. Vammaisuuden ja sosiaalityön narratiivisista ehdoista Baldwin kirjoittaa yhdessä Mary-Dan Johnstonin kanssa.

Baldwin avaa narratiivisuuden perusteita ontologian, tietoteorian ja kommunikaation ulottuvuuksilla; narratiivisuus ontologisena oletuksena ymmärtää tarinat maailmaa jäsentävinä elementteinä, mikä tarkoittaa käytännössä sitä, että ihmiset jäsentävät olemistaan ja tekojaan tarinanmallisina. Tietoteoreettinen sidos viittaa käsitykseen tietämisen tavasta ja tiedon luotettavuudesta, ja tämän Baldwin sitoo vuorovaikutukseen ja kommunikaatioon ihmisten ja tarinoiden kesken.

Baldwin jakaa narratiivisuuden vahvaan ja heikkoon versioon ja kiinnittää lähestymistapansa vahvaan kantaan. Heikossa versiossa narratiivisuus ymmärretään ihmisten ja maailman tajuamisen "hyödyllisenä välineenä", kun taas vahvan version mukaan narratiivisuus rakentaa minuutta ja maailmaa. Baldwin esittelee neljä pääsyytä vahvan narratiivisen asemoinnin puolesta sosiaalityössä: (1) ymmärrys asiakkaasta ja hänen elämäntilanteestaan, (2) sosiaalityön itseymmärrys, (3) ymmärrys kerronnan [ja elämän] rakentumisesta ja ehdoista sekä (4) rakenteellinen ulottuvuus, jonka voisi kääntää laveasti rakenteelliseksi vaikuttavuudeksi. Lisäksi Baldwin huomauttaa, että valta ja vallankäyttö läpäisee narratiivien dynamiikkaa, retorisia strategioita ja argumentointikäytäntöjä.
Käytännössä tämä tarkoittaa sitä, että sosiaalityön tiedonmuodostus, kirjaaminen ja selonteot ovat narratiivisia, ja tämän ilmiön seurausten ymmärtäminen on sosiaalityön vaikuttavuuden kannalta olennaista. Näistä lisää seuraavissa esimerkeissä.

Baldwinin tarkempaan syyniin valitsemat sosiaalityön alat, lastensuojelu, mielenterveys ja vammaisuus, toimivat narratiivisen sosiaalityön esimerkkitapauksina. Narratiivisuus sisältää kriittisen suhtautumisen tarinoiden käyttöön esimerkiksi asiantuntija-, ammatti- ja politiikkakäytössä; Baldwin ottaa esimerkin lastensuojelusta,jossa hän kuvaa äiti-narratiivin muodostamista sosiaalityön asiakastapauksessa. Narratiivia eli käytännössä asiakastapauksen käsittelyä - rakennettiin tietyn, patologisen tarinamallin mukaan ja tätä tarinamallia vastaanolevat faktat sulkeistettiin pois (ks. tapauksesta ja sen päätöksestä Euroopan ihmisoikeustuomioistuimessa myös Baldwin 2005). Narratiivi on vahva vaikuttamisen ja myös vallankäytön väline, ja narratiivisuuden sekä ympäröivien tarinamallien vaikutuksen ymmärtäminen ja kriittinen puntarointi (voi) auttaa asiantuntijaa ammattikäytännöissään, kohentaa palveluita ja asiakkaan vaikutusmahdollisuuksia.

Toinen esimerkki koskee narratiivista sosiaalityötä ja ruumiillisuutta, joka tuodaan myös tässä teoksessa esille erityisesti vammaisuuden yhteydessä. Tämä siksi, että ruumiillisuus määrittää toimijuuden ehtoja. Toisekseen siksi, että vallitseva vammaisuustulkinta (eli -narratiivi) perustuu lääketieteellistettyyn yksilöpatologiaan, eli toisin sanoen vammaisuus ymmärretään $\mathrm{yk}-$ 
silön ei-toivottuna (ruumiillisena) erilaisuutena. Ruumiillisuuden valtavirtatarinat rakentavat toimijuuden ehtoja, ja narratiivisessa sosiaalityössä on mahdollista uudelleen muokata ja vastustaa (narrative resistance) esimerkiksi epätasa-arvoistavia ruumiillisen toimijuuden mallitarinoita; tämä kiinnittyy vahvasti myös narratiivisen sosiaalityön etiikkaan, jossa ydinasioita ovat kertomisen ja kuulluksi tulemisen ehdot sekä toimijuus (ks. myös Tarvainen 2019).

Baldwinin tavoite on ollut "havainnollistaa, miten narratiivisuutta voidaan soveltaa sosiaalityössä”, ja teos paitsi havainnollistaa, niin myös kokoaa, kontekstualisoi ja motivoi narratiivista sosiaalityötä. Teos on erittäin sujuvasanainen ja selkeä. Kirjan lopuksi Baldwin kehottaa lukijaa palaamaan alkuun ja lukemaan tätäkin teosta narratiivisen kriittisyyden kautta: Miten kirjan rakenne toimii retorisena keinona ja rakentaa ymmärrystä sosiaalityöstä? Baldwinin valinta oli siis aloittaa sosiaalityön arvoista, edetä toimintaympäristön (etiikan ja politiikan) kautta tiettyjen alueiden käytännön esimerkkien tarkasteluun. Lisäksi Baldwin kehottaa pohtimaan miten (jos mitenkään) hänen esittelemänsä esimerkit "resonoivat" esimerkiksi työkokemuksesi tai kuulemiesi tapausten kanssa. Baldwin päättää Thomas Kingin $(2003,29)$ sanoihin, jotka voisi vapaasti suomentaa esimerkiksi näin:

Tarina on nyt sinun. Tee sillä mitä tahdot. Kerro ystäville. Pistä tarina vaikka televisioon. Unohda se. Mutta älä sano vuosien kuluttua että olisit tehnyt asiat toisin jos vain olisit kuullut tämän tarinan. Olet kuullut sen nyt.

\section{KiRJALlisUUS}

Baldwin, Clive (2005) Who needs fact when you've got narrative? The case of $\mathrm{P}$, $C \& S$ vs United Kingdom. International Journal for the Semiotics of the Law 18 (3-4), 217-241.

Hall, Christopher (1997) Social work as narrative: Storytelling and persuasion in professional texts. Aldershot: Ashgate.

King, Thomas (2003) The truth about stories: A native narrative. Toronto, ON: House of Anansi Press.

Tarvainen, Merja (2019) Ableism and the life stories of people with disabilities. Scandinavian Journal of Disability Research 21 (1), 291-299. DOI: http://doi. org/10.16993/sjdr.632 